\title{
Erratum to: Contamination of Selected Organochlorine Pesticides (OCPs) in Sediment from CauBay River, Hanoi
}

\author{
Vu Duc Toan
}

Published online: 2 April 2014

(C) Springer Science+Business Media New York 2014

Erratum to: Bull Environ Contam Toxicol (2013)

90:132-135

DOI 10.1007/s00128-012-0877-3

The author would like to publish this erratum to add a new phrase in the Acknowledgments section to the original published article.

\begin{abstract}
Acknowledgments This research was funded by the Vietnam National Foundation for Science and Technology Development (NAFOSTED) under Grant Number 105.09-2012.09. The author would also like to thank Vietnam Water Resources University for their support.
\end{abstract}

The online version of the original article can be found under doi:10.1007/s00128-012-0877-3.

V. D. Toan $(\bowtie)$

Vietnam Water Resources University, 175 Tay Son Street, Hanoi, Vietnam

e-mail: vuductoan@wru.edu.vn; vuductoan2001@yahoo.com 